Protestantismo em Revista é licenciada sob uma Licença Creative Commons.

\title{
O Sagrado no culto protestante reformado: uma reflexão desde dentro
}

\author{
The Sacred in protestant reformed cult: an endogenous reflection
}

Marcelo Lopes*

\begin{abstract}
Resumo
O ano de 2017 é bastante simbólico para os protestantes, pois nele comemoramos duas datas bastante significativas: os 500 anos da Reforma Protestante e os 100 anos do lançamento do livro O Sagrado do teólogo protestante Rudolf Otto. De natureza preambular, o presente ensaio tem por escopo problematizar aspectos do sagrado no culto protestante reformado, tomando como referência a Igreja Presbiteriana do Brasil. O texto está estruturado em três tópicos: uma brevíssima sinopse histórica do culto reformado no Brasil, os dois modelos de culto mais adotados pelos protestantes; além, é claro, de problematizar sumariamente, aspectos do sagrado no culto reformado, e isso de forma endógena. Trata-se, portanto, de um esforço heurístico de iluminar uma temática cara, nesta data deveras expressiva.
\end{abstract}

\section{Palavras-chave \\ O Sagrado. Numinoso. Culto Reformado.}

\begin{abstract}
The year 2017 is quite symbolic for protestants, as we celebrate two very significant dates: the 500th anniversary of the Protestant Reformation and the 100th anniversary of the publication of book The Sacred of protestant theologian Rudolf Otto. Of preambular nature, the present essay has the scope to problematize aspects of the sacred in the reformed Protestant cult, taking as reference the Presbyterian Church of Brazil. The text is structured in three topics: a very brief historical synopsis of the reformed cult in Brazil, the two models of worship most adopted by Protestants; Besides, of course, to briefly problematize aspects of the sacred in the reformed cult, and this in an endogenous way. It is, therefore, a heuristic effort to illuminate an expensive theme on this very significant date.
\end{abstract}

\section{Keywords}

The Sacred. Numinous. Reformed Cult.

[Texto recebido em maio de 2017 e aceito em junho de 2017, com base na avaliação cega por pares realizada por pareceristas ad hoc]

* Bacharel em Teologia (FAECAD). Especialista em Ciências da Religião (Faculdade de São Bento/RJ). Mestre e Doutorando Ciência da Religião (Religião, Sociedade e Cultura - UFJF). Integrante do Núcleo de Estudos em Protestantismo e Teologias (NEPROTES - UFJF/CNPq). Presbítero regente, atualmente servindo no Conselho da $1^{\mathrm{a}}$ Igreja Presbiteriana de Juiz de Fora. E-mail: montanhista-ms@hotmail 


\section{Considerações iniciais}

É bem sabido que o culto cristão desde sua distinção do judaísmo helenístico no início da era apostólica representava o centro da vivência religiosa dos adeptos da "seita dos Nazarenos". ${ }^{1}$ Nesse contexto, o cristianismo primitivo, recém-egresso do judaísmo, herdara a reunião comunitária semanal como padrão para a sua celebração religiosa pública. Inicialmente, inclusive, procuraram não distanciarem-se dos serviços religiosos nas sinagogas e no próprio templo, sem abdicar, contudo, das reuniões nas casas dos neoconversos.

Entrementes, no decurso de seu desenvolvimento histórico, o cristianismo desenvolveu uma ampla gama de matizes litúrgico-teológicas. Fato que dificulta até mesmo aos mais experientes liturgos a definição, stricto sensu, de culto cristão, devido à variedade de formas e conteúdos que esse gradiente comporta. Nesse sentido, André Leonardo Chevitarese - pesquisador do cristianismo primitivo - chega mesmo a propor a pluralização do termo para cristianismos, alegando que "o seu uso no plural explicita uma forma de ver o longo processo histórico de disseminação do movimento instaurado por Jesus de Nazaré". ${ }^{2}$

Embora essa temática nos seja cara e sobremodo instigante, não se constitui o cerne deste ensaio. Nosso escopo aqui se restringe ao sagrado no culto, circunscrito ao gradiente das denominações oriundas da Reforma Protestante, e, mais especificamente, àquelas de matriz reformada, cujo acento recairá naquela que é sua maior representante, numericamente falando, no Brasil: a Igreja Presbiteriana do Brasil (IPB). Ademais, não seria exequível aprofundar em poucas laudas quaisquer vertentes do protestantismo sob o lócus litúrgico, quiçá exaurir o conceito de sagrado no gradiente protestante. Portanto, nosso fulcro será o de trabalhar simultaneamente o conceito de sagrado, mormente segundo postulou Rudolf Otto, e seu papel no culto reformado presbiteriano, sobretudo no Brasil.

\section{O culto reformado no Brasil: uma brevíssima sinopse}

Não seria exagero algum afirmar que a Reforma Protestante representa a inauguração de uma nova era no cristianismo ocidental, cujas reverberações ecoam até os dias atuais. Basta fazer referência ao movimento pentecostal e suas idiossincrasias para exemplificar a magnitude das reverberações da Reforma ainda no tempo presente. Todavia, para o nosso fito aqui, é preciso situar desde logo, numa perspectiva cronológica, a questão do culto reformado no Brasil.

1 BÍBLIA TRADUÇÃO ECUMÊNICA. São Paulo: Loyola, 1994. Atos dos Apóstolos 24.5.

2 CHEVITARESE, André Leonardo. Cristianismos: questões e debates metodológicos. Rio de Janeiro: Klinē, 2011. p. 9. 
Sob o prisma historiográfico, a presença reformada remete ao início da colonização do Brasil. Segundo Bicalho, "em novembro de 1555 três navios franceses sob o comando por [sic!] Nicolas Durand de Villegagnon, nobre cavaleiro da Ordem de Malta, chegaram à Baía da Guanabara com o intuito de fundar uma colônia". ${ }^{3}$ Nesse sentido, Knauss chama a atenção para o fato de que

entre 1555 e 1560, os acontecimentos em torno da ocupação francesa na Baía de Guanabara entrelaçaram diferentes fatos que caracterizam a historicidade da empresa colonizadora, demarcando o evento como expressão do seu tempo. Desse modo, destaca-se a liderança do comandante Nicolas Durand de Vilegagnon, cavaleiro da Ordem Malta, com voto de castidade e pobreza, assim como chama atenção a participação de protestantes franceses, conhecidos como huguenotes. ${ }^{4}$

Aqui cumpre destacar que Villegagnon foi colega de universidade de Calvino e chegou a trocar correspondência com este último sobre a empreitada francesa na Guanabara. A propósito disto, salientamos que, conquanto efêmera, a presença dos calvinistas ou huguenotes no Brasil colonial foi deveras intensa. Afirmamos isso em função da relevância de seus feitos, dos quais podemos citar alguns mais destacados, tais como: a celebração do primeiro culto protestante reformado no dia 10 de março de 1557, a celebração da primeira ceia em 21 de março de 1557, e, talvez o mais proeminente feito, a elaboração da primeira confissão de fé reformada: a Confissão de Fé da Guanabara ou Confissão Fluminense. Ademais, os huguenotes Jean du Bourdel, Matthieu Verneil e Pierre Bourdon foram os primeiros mártires reformados no Brasil, os quais foram executados por Villegagnon sob o pretexto de discordâncias doutrinárias. ${ }^{5}$

Inclusive, segundo o historiador da IPB Alderi Souza de Matos,

a Confissão de Fé da Guanabara ou Confissão Fluminense foi escrita em resposta às perguntas ou quesitos apresentados por Villegaignon [sic!]. Estritamente, trata-se de um credo, pois quase todos os artigos começam com a palavra "cremos". Todavia, a sua extensão e a variedade de temas a coloca na categoria das confissões de fé, comuns na época da Reforma. Na verdade, é um dos primeiros documentos confessionais reformados. A

3 BICALHO, Maria Fernanda B. A França Antártica, o corso, a conquista e a "peçonha luterana". História, São Paulo, n. 27, v. 1, p. 29-50, 2008. p. 32. Disponível em: <http://www.scielo.br/pdf/his/v27n1/a04v27n1.pdf>. Acesso em: 25 dez. 2016.

4 KNAUSS, Paulo. No rascunho do Novo Mundo: os espaços e os personagens da França Antártica. História, São Paulo, n. 27, v. 1, p. 143-153, 2008. p. 144. Disponível em: <http:/ / www.scielo.br/pdf/his/v27n1/a09v27n1.pdf>. Acesso em: 25 dez. 2016. Grifo nosso.

5 Para um aprofundamento no assunto indicamos ao leitor o livro: MARIZ, Vasco; PROVENÇAL, Lucien. Villegagnon e a França Antártica: uma reavaliação. Rio de Janeiro: BibliEx/Nova Fronteira, 2001. 
Confissão Galicana (1559), a Confissão Belga (1561), o Catecismo de Heidelberg (1566) e a Confissão de Fé de Westminster (1648) são todos posteriores. ${ }^{6}$

No entanto, a fé reformada somente lograria êxito no Brasil com a empresa missionária norte-americana em meados do século XIX, com o envio do pastor presbiteriano Ashbel Green Simonton. O Rev. Simonton chegou ao Brasil em 12 de agosto de 1859. Então com apenas 26 anos de idade esse missionário conseguiu implantar o presbiterianismo no Brasil. Faleceu de febre amarela aos 36 anos, tendo deixado um legado significativo, qual seja: restou de sua labuta uma igreja estabelecida com um presbitério (Presbitério do Rio de Janeiro - 1865), um seminário (Seminário Primitivo 1867) e um jornal (Imprensa Evangélica - 1864). Trata-se de um legado de não somenos importância, dada a curta tessitura temporal de seu ministério no Brasil.

Assim, pensamos ter proporcionado com essa visada inicial um panorama que contemple o estabelecimento do culto protestante de matriz reformada em nosso país. Obviamente não esgotamos o assunto, aliás, sequer arranhamos o arcabouço históricocultural que envolve o estabelecimento dessa tradição evangélica. Passemos agora à disposição de análise do culto propriamente dito.

\section{Dois modelos de culto protestante}

Numa tentativa não exaustiva de classificação cúltica, embasando-nos na tipologia proposta por Prócoro Velasques Filho, pode-se dividir as igrejas protestantes em litúrgicas e não-litúrgicas. ${ }^{7}$ Segundo esse pesquisador do protestantismo brasileiro,

igrejas litúrgicas são aquelas que, por tradição histórica, mantêm uma ordem de culto pré-estabelecida, um conjunto de ritos solenes, uma simbologia expressa em trajes apropriados para cada rito e estação do calendário litúrgico, e em aparatos do culto e na arquitetura. A tradição litúrgica não é uma criação espontânea, mas uma acumulação de dados e fatos que se somam no decorrer de séculos. (...) Nas igrejas litúrgicas, os ritos (Eucaristia, Batismo, Matrimônio, Confirmação, Ordenação, etc.) ocupam um lugar central na vida cúltica da comunidade. Aqui, embora a pregação ocupe um lugar destacado, o centro é ocupado pelos ritos. As orações são preparadas antecipadamente e são, via de regra, escritas. A postura do celebrante e dos demais participantes do culto é préestabelecida, bem como os seus gestos. O centro visual do culto é o altar, com as velas (símbolo da presença do Espírito Santo), os elementos da Eucaristia e a cobertura (geralmente uma toalha) obedecendo as cores da estação litúrgica. O púlpito e o lecionário ocupam as laterais do altar, enquanto que a cruz e a Bíblia são colocadas em lugar bem visível e central.

6 MATOS, Alderi Souza de. A França Antártica e a Confissão de Fé da Guanabara. CPAJ. Disponível em: <http://www.mackenzie.br/6996.98.html>. Acesso em: 25 dez. 2016. Grifos do autor.

7 VELASQUES FILHO, Prócoro. O culto protestante: características, ênfases e teologia. Estudos de Religião, São Bernardo do Campo, ano 1, n. 2, p. 61-85, out. 1985. 
O oficiante veste toga ou batina, que podem ser cobertas com outros paramentos litúrgicos. Os participantes (assistentes ou ouvintes) recebem a liturgia escrita e o hinário. De modo geral, o uso da Bíblia é substituído pelo texto escrito da liturgia, que contém as leituras para o dia ou antífonas. No Brasil, são duas as Igrejas protestantes de tradição litúrgica: a luterana e a anglicana. ${ }^{8}$

Por outro lado, as

igrejas não-litúrgicas são aquelas que, por tradição herdada do pietismo, do puritanismo e do avivamento (séc. XVII, XVIII e XIX), praticam um culto "espontâneo", isto é, rejeitam qualquer ordem de culto pré-estabelecida, escrita, rituais solenes, vestes e aparatos litúrgicos, e os símbolos. As Igrejas não-litúrgicas caracterizam-se pela oposição à tradição litúrgica por identificarem-na com o catolicismo romano, de quem são inimigos mortais. Em outras palavras, tudo aquilo que se parecer ao catolicismo romano, deve, não só ser deixado de lado, como deve ser condenado. É a busca de uma identidade e de uma afirmação através do corte e da condenação de suas raízes, isto é, do catolicismo romano. Por exemplo, a liturgia e os ritos pré-estabelecidos de forma escrita são condenados por se parecerem com a "missa". O mesmo acontece com a centralidade do altar, as velas, as vestes, os aparatos, a cruz e quaisquer outros símbolos litúrgicos. No culto das igrejas não-litúrgicas, a centralidade do espaço é ocupada pelo púlpito. $\mathrm{O}$ púlpito é o lugar do qual o pregador anuncia a "palavra de Deus" e por isto ocupa o lugar que, no culto das igrejas litúrgicas, estaria o altar. Consequentemente, o sermão torna-se a parte mais importante do culto. ${ }^{9}$

As igrejas não-litúrgicas no Brasil mais expressivas, numericamente falando, são provenientes de missões norte-americanas, dentre as quais destacam-se os presbiterianos, congregacionais, metodistas e batistas. Em nosso caso específico, a IPB é fruto direto da missão da Igreja Presbiteriana do Norte dos Estados Unidos. Rubrique-se que o culto na IPB é bastante simples, ${ }^{10}$ sem paramentação para os ministros, ou utilização de aparatos ou ornamento, bem como a ausência de uma arquitetura sacra para os templos, cujo formato, normalmente é de um salão.

Essa simplicidade do culto reformado da IPB tem raízes históricas distantes, isto, é, na Reforma propriamente dita. Para que possamos entender melhor a assertiva anterior, é preciso que nos lembremos das posturas díspares entre os reformadores com relação à constituição do culto. Ora, isso nos remete às “atitudes divergentes de Lutero dum lado e

8 VELASQUES FILHO, 1985, p. 70.

9 VELASQUES FILHO, 1985, p. 71.

10 Ressalte-se que simples, como usado aqui, não é sinônimo de depauperado. Tão pouco por não ter uma liturgia específica, não significa que há frouxidão litúrgica na IPB. O culto presbiteriano é orientado por rubricas estritamente bíblicas. Para um maior esclarecimento do assunto, recomendamos o leitor ao texto: CUNHA, Gladson Pereira da. O culto presbiteriano como performance do tempo sagrado. Protestantismo em Revista, São Leopoldo, v. 31, p. 94-108, maio/ago. 2013. Disponível em: <http:// periodicos.est.edu.br/index.php/nepp/article/viewFile/795/1035>. Acesso em: 25 dez. 2016. 
de Zwínglio e Calvino do outro. Lutero permitia a permanência de tudo que, ao seu ver, não feria princípios do Evangelho; Zwínglio e Calvino expurgavam tudo não preceituado pelo evangelho". ${ }^{11}$ Daí resulta, necessariamente, duas ênfases cúlticas que trabalharemos mais adiante.

Essa distinção litúrgica é importante na medida em que ressalta um aspecto do culto reformado que possui íntima relação com o nosso objeto neste ensaio. $O$ fato de a homilia ser o centro do culto reformado possui implicações profundas para a concepção do sagrado no culto. Antes de problematizarmos essas implicações, porém, importa que explicitemos um acento cultural que encontra-se imiscuído nesse contexto.

Trata-se de uma marca distintiva e dentro de um processo histórico específico. As igrejas da Reforma Protestante como um todo, e a tradição reformada, particularmente, valorizaram a educação, a formação e o intelectualismo. Esse apreço configurou-se uma característica do protestantismo puritano-pietista. Corroborando esse timbre, basta que nos lembremos, por exemplo, que vários pietistas foram proeminentes na história da Martin-Luther-Universität Halle-Wittenberg. Já os puritanos, destacados desde a Universidade de Oxford, na Inglaterra; foram os fundadores, nos Estados Unidos, de universidades como Harvard, Yale, Columbia e Princeton, por exemplo.

Mas o fato é que essa questão da racionalidade guarda relação com a questão da centralidade da homilia no culto reformado. Tal tese já foi trabalhada por Antonio Gouveia Mendonça, ao relembrar que

um historiador americano contemporâneo, André Siegfried, ao construir as tipologias dos vários ramos protestantes norte-americanos, coloca os congregacionais e presbiterianos, descendentes diretos da tradição dos puritanos da Nova Inglaterra, na categoria dos intelectuais. Volto a insistir que a centralidade da pregação em detrimento da do ritual podia muito bem estar por trás dessa preocupação intelectual e acadêmica. ${ }^{12}$

O mesmo Mendonça, em outro texto mais antigo, afirma que

o protestantismo do século XIX pagou pesados tributos ao racionalismo. Não há nenhuma necessidade de nos estendermos muito nesta questão aqui, mas somente mostrar como essa influência trouxe contribuição para o modelo de culto protestante brasileiro. O racionalismo exige "verdades", e em nome da verdade sacrifica tudo o mais, sentimentos, emoções, beleza e mistério. Sobretudo não pode haver mistérios, zonas nebulosas do conhecimento que mantêm a mente humana à distância enquanto desafiam suas intuições e seus temores. Num dado momento, o racionalismo,

11 REILY, Duncan Alexander. O culto no Protestantismo Puritano-Pietista. Estudos de Religião, São Bernardo do Campo, ano 1, n. 2, p. 89-102, out. 1985. p. 97.

12 MENDONÇA, Antonio Gouvêa. O celeste porvir: a inserção do protestantismo no Brasil. São Paulo: ASTE/Pendão Real; São Bernardo do Campo: IMS, 1995. p. 52. Grifo nosso. 
aparentemente vitorioso pelas suas conquistas científicas e tecnológicas, pelo rigor dos imensos e ambiciosos tratados dos pensadores das ciências humanas, colocou a religião ocidental contra a parede; ou ela aceitava o desafio e partia para a demonstração nua, crua e irretorquível de suas verdades, ou estava condenada à morte..$^{13}$

Ressalte-se, no entanto, que não se trata de uma racionalidade por si só ou despropositada. Antes, havia uma exigência cultural e uma necessidade pragmática. Explico: trata-se da característica das religiões monoteístas de serem exclusivistas da verdade. Tal característica é exacerbada no protestantismo, pois, não sem motivo, as denominações oriundas da Reforma produziram confissões de fé que, para elas, seriam a expressão da verdadeira interpretação da Bíblia. Além disso, a polêmica também marcou o movimento reformador, inclusive com os pais Lutero e Calvino, por exemplo.

Trata-se, portanto, de algo muito caro às denominações protestantes, pois, em última instância, a intelectualização da fé intentou cristalizar de modo sistematizado a verdade. A Confissão de Fé de Augsburgo, a Confissão de Fé de Westminster, os Cânones de Dort, a Confissão Belga, etc., são expressões desse intento de sistematização da verdade, com ênfase exclusivista.

As implicações disso para o culto reformado são óbvias, sobretudo em locais onde o protestantismo não era a religião oficial ou majoritária, como no caso do Brasil colonial.

Nesse sentido, não é difícil perceber o poder com que o racionalismo entrou no protestantismo brasileiro. Os missionários pioneiros encontraram no Brasil uma religião estabelecida [catolicismo romano] e não havia como desalojá-la, ou pelo menos abrir alguns espaços, senão demonstrando sua "falsidade". O núcleo da nova mensagem religiosa era a luta da "verdade" contra o "erro". Daí, o feliz casamento da retórica tradicional brasileira com a retórica sacra dos "revivals". Se o objetivo central do culto era convencer os presentes a sair do "erro" e a aceitar a "verdade", os sermões se tornaram casa vez mais aprimoradas peças de oratória com as clássicas partes de introdução ou proposta, argumentação e prova e conclusão e apelo. $\mathrm{O}$ tempero era dado pelo pietismo que funcionava como alavanca sentimental para mover as vontades que, preguiçosas, não respondiam ao apelo da razão. Como consequência, reforçou-se a centralidade da pregação no culto; num dado momento a pregação "era" o culto. ${ }^{14}$

Isso é reforçado no presbiterianismo por um motivo relativamente simples, mas deveras sintomático, qual seja, a preparação de seus quadros pastorais. Leonildo Silveira Campos, 15 amparado em estudos de Jean-Paul Willaime, assevera que o presbiterianismo

13 MENDONÇA, Antonio Gouvêa. A crise do culto protestante no Brasil. Estudos de Religião, São Bernardo do Campo: UMESP, ano 1, n. 2, p. 31-60, out. 1985. p. 44-45.

14 MENDONÇA, 1985, p. 45.

15 Pastor presbiteriano (IPI). Doutor em Ciências da Religião. Professor da Universidade Presbiteriana Mackenzie. 
brasileiro se mantém irredutível quanto a uma "educação cristã e teológica, fortemente teóricas, destinadas a formar especialistas religiosos [pastores] com perfil de doutores" ${ }^{16}$

Se somarmos às questões anteriores o surgimento do pentecostalismo no início do século XX, com todo seu apelo emocional e atitude anti-intelectual, veremos que a maior parte das igrejas protestantes buscaram distanciar-se do movimento pentecostal, acusando-o, inclusive, de modelo religioso de irracionalidade. $\mathrm{O}$ acento na racionalidade ganhou o reforço da moderação e da sobriedade nos reduzidos gestos e limitadas manifestações no culto reformado, cujo intento era a distinção dos "exageros" pentecostais.

Portanto, o culto reformado tornou-se demasiado racional e solene, perdendo quaisquer possibilidades de espontaneidade, pois até mesmo o bater palmas durante o período de cânticos não era bem visto, antes, era uma "má" nifestação a ser evitada a todo custo, inclusive em detrimento da possibilidade da irrupção do sagrado no culto. Tratavase da domesticação do sagrado selvagem, conforme postulou Roger Bastide. ${ }^{17}$

Assim, após termos iluminado esse processo de reificação cúltica no seio reformado, é, por dever de justiça, que precisamos alertar o leitor que esse processo configurou-se uma tendência nas igrejas presbiterianas. No entanto, de modo algum é possível afirmar que foi um movimento uniforme, pois há igrejas na IPB que possuem uma liturgia leve sem, contudo, abrirem mão de sua confessionalidade. Por outro lado, há igrejas presbiterianas que, exceção feita aos artefatos, se assemelham muito a igrejas litúrgicas, dada a fossilização de sua liturgia. O que acima foi exposto, tratava-se, portanto, de uma tendência que em alguma medida, ainda reverbera na IPB.

Aqui precisamos, também, começar a problematizar a questão mais específica deste ensaio, qual seja, o sagrado no culto reformado. Ora, do ponto de vista fenomenológico, as religiões são expressões culturais caracterizadas pela busca da hierofania, epifania ou teofania, ou seja, a manifestação do sagrado. Ou, dito de forma teológica, o fiel vai à igreja para encontrar-se com Deus e para cultuá-lo comunitariamente.

Nesse sentido, o que o fiel ou nativo espera, em última instância, é que Deus se manifeste. Face ao quadro exposto nas laudas antecedentes, algumas perguntas naturalmente emergem, dentre as quais: no culto reformado, o sagrado é "livre" para se manifestar? Como o sagrado se manifesta no culto reformado? Como o reformado lida com a manifestação do sagrado?

16 CAMPOS, Leonildo Silveira. Pentecostalismo e Protestantismo Histórico no Brasil: um século de conflitos, assimilação e mudanças. Horizonte, Belo Horizonte, v. 9, n. 22, p. 504-533, jul./set. 2011. p. 525. Disponível em: <http://periodicos.pucminas.br/index.php/horizonte/article/view/P.21755841.2011v9n22p504/2909>. Acesso em: 20 maio 2015.

17 BASTIDE, Roger. O sagrado selvagem e outros ensaios. São Paulo: Companhia das Letras, 2006. 


\section{O sagrado no culto reformado: problematizações}

Desde logo é preciso pontuar que nossa referência quanto à ideia de sagrado é de Rudolf Otto, mormente em sua obra: O Sagrado: aspectos irracionais na noção do divino e sua relação com o racional. ${ }^{18}$ No entanto, talvez seja importante, e até mesmo necessário, fazer referência a outro fenomenólogo que também trabalhou magistralmente a ideia do sagrado, com outro viés, mas de igual relevância, trata-se de Mircea Eliade e sua obra: $O$ sagado e o profano. ${ }^{19}$

Segundo Eliade, para o homo religiosus, há basicamente dois modos de ser no mundo: o sagrado e o profano. ${ }^{20} \mathrm{~A}$ esfera do sagrado, a qual pertenceria à divindade e aos seres celestiais, estaria disposta num plano supranatural, enquanto que o nosso mundo, o mundo dos homens, estaria alinhado com o profano. Assim, "quando o sagrado se manifesta por uma hierofania qualquer, não só há rotura na homogeneidade do espaço, como também revelação de uma realidade absoluta, que se opõe à não-realidade da imensa extensão envolvente. A manifestação do sagrado funda ontologicamente o mundo". ${ }^{21}$

Isto posto, nosso intuito aqui não é propor definições, inclusive para a ideia do sagrado, senão apontar sentidos nos quais essa terminologia possa se enquadrar, sem, contudo, evidentemente, exaurir-se. Até mesmo porque, segundo Tersteegen, "um Deus compreendido não é um Deus". Destarte, "o sagrado, no sentido pleno da palavra, é para nós, portanto, uma categoria composta. Ela apresenta componentes racionais e irracionais. (...) é preciso afirmar com todo o rigor que em ambos os aspectos se trata de uma categoria estritamente a priori" ${ }^{22}$

Já rubricamos a característica racional que marca distintivamente a tradição protestante como um todo; e a reformada, particularmente. Nesse sentido, Otto destaca que em

qualquer idéia teísta de Deus, sobretudo para a cristã, é essencial que ela defina a divindade com clareza, caracterizando-a com atributos como espírito, razão, vontade, intenção, boa vontade, onipotência, unidade da essência, consciência e similares e que ela portanto seja pensada como correspondendo ao aspecto pessoal-racional, como o ser humano o percebe em si próprio de forma limitada e inibida. (...) E a religião que os reconheça é e afirme é, nesse sentido, uma religião racional. ${ }^{23}$

18 OTTO, Rudolf. O Sagrado: aspectos irracionais na noção do divino e sua relação com o racional. São Leopoldo: Sinodal/EST; Petrópolis: Vozes, 2007.

19 ELIADE, Mircea. O sagrado e o Profano: a essência das religiões. São Paulo: Martins Fontes, 2008.

20 ELIADE, 2008.

21 ELIADE, 2008, p. 26. Grifo do autor.

22 OTTO, 2007, p. 150.

23 OTTO, 2007, p. 33. 
Para o nosso autor, "o cristianismo possui esses conceitos e os possui com maior clareza, nitidez e completude". ${ }^{24}$ Assim, não seria de estranhar que o aspecto racional obtivesse primazia no culto reformado. "Porém, mesmo que os atributos racionais geralmente ocupem o primeiro plano, eles de forma alguma esgotam a idéia da divindade, uma vez que se referem e têm validade apenas para algo irracional" ${ }^{25}$

Assim, o sagrado cristão possui, notadamente, aspectos racionais, morais e irracionais. Porém, quando nos referimos ao sagrado propriamente dito aqui, queremos designar a teofania descontada de seus aspectos racionais e morais ou éticos. Trata-se, portanto, do aspecto não definível de modo intelectivo, mas somente sentido, intuído, percebido. Contudo, "por irracional não entendemos o vago e néscio, ainda não submetido à razão, nem a birra das pulsões individuais ou das engrenagens do mundo contra a racionalização". ${ }^{26}$

Quando nos referimos ao sagrado no culto reformado, trata-se daquela percepção espiritual que somente pode advir das regiões mais abissais da experiência religiosa legítima, e que, portanto, é inapreensível conceitualmente, mas apenas sentido, vivido, experienciado. Com o intuito de oferecer uma perspectivação disso, Rudolf Otto utiliza-se do sentimento do numinoso para que o leitor possa inferir os efeitos do sagrado sobre o homo religiosus. Assim, o termo numinoso refere-se, primordialmente, à percepção do sagrado pelo humano em sua irracionalidade, isto é, em sua inapreensibilidade conceitual, bem como seu efeito sobre o homem.

De maneira bastante sistemática, Otto trabalha a ideia de aspectos do numinoso, dentre os quais trabalharemos alguns aqui. Daqueles que nos interessam mais pormenorizadamente neste ensaio, podemos citar em primeiro lugar o sentimento de criatura ante ao numinoso. Para tentar exemplificar esse sentimento, Otto cita a experiência de Abraão:

\footnotetext{
"Tomei a liberdade de falar contigo, eu que sou poeira e cinza". O "sentimento de criatura" na verdade é apenas um efeito colateral, subjetivo, é por assim dizer a sombra de outro elemento de sentimento (que é o receio), que sem dúvida se deve em primeiro lugar e diretamente a um objeto fora de mim. Esse é justamente o objeto numinoso. Somente quando se vivencia a experiência do nume, como no caso de Abraão, ou quando se sente algo que tenha caráter numinoso, ou seja, somente pela aplicação da categoria do numinoso a um objeto real ou imaginário é que o sentimento de criatura pode surgir como reflexo na psiquê. ${ }^{27}$
}

24 OTTO, 2007, p. 33.

2 OTTO, 2007, p. 34. Grifo do autor.

26 OTTO, 2007, p. 33.

27 OTTO, 2007, p. 33. Grifos do autor. 
Na sequência, Otto destaca "o sentimento de criatura" como reflexo da numinosa sensação de ser objeto na autopercepção, no qual

\begin{abstract}
"a sensação de dependência", ou melhor, o sentimento de criatura é apenas efeito subsequente, isto é, uma depreciação que o sujeito experimenta em relação a si mesmo. Em outros termos: o sentimento subjetivo de "dependência absoluta" pressupõe uma sensação de "superioridade (e inacessibilidade) absoluta" do numinoso. ${ }^{28}$
\end{abstract}

Nesse sentido, emerge um aspecto do numem que guarda estreita relação com um dos principais acentos da teologia reformada, qual seja, o da absoluta soberania de Deus. Este aspecto do numem é o mysterium tremendum. Trata-se da sensação ante um Deus absolutamente soberano praticamente inacessível que gera, no cultuante, certo assombro, terror e, nas palavras de Otto, um "receio demoníaco". ${ }^{29}$

Aqui já começamos a compreender o porquê de algumas nuances do culto reformado. Ora no fim do tópico anterior nos perguntamos: O Sagrado é livre para se manifestar no culto reformado? Essa pergunta, embora possa parecer um tanto tácita, encontra esteio na prática litúrgica das igrejas reformadas, mormente a IPB. Referimo-nos ao apelo racional em detrimento das manifestações emocionais, principalmente aquelas que implicam em movimentos corporais "exagerados".

Essa distinção é importante, pois difere da vertente pentecostal no sentido de uma busca pelo êxtase que, segundo os quais, dá-se pela ação miraculosa do Espírito Santo. No limite, é possível dizer que o cultuante pentecostal, em sua experiência extática, é possuído pelo Espírito Santo. Tal percepção cúltica é doutrinariamente fundamentada na alegação teológica da possibilidade da reatualização do mito fundante, isto é, o evento de pentecostes narrado em Atos 2. Nesse sentido, embora a fundamentação se encontre nas Escrituras, é o rito que atualiza o mito.

Todavia, conforme percebemos nos parágrafos precedentes, para o nativo reformado é o Deus absolutamente soberano que se manifesta no culto. Ele, por sua soberania, pode manifestar-se como quiser. Assim, nosso suposto é que justamente por este motivo, isto é, por estar na presença do Deus Soberano, que os fieis evitam as "má"nifestações exacerbadas, as corporais sobretudo, com receio de despertarem o "zelo de Javé", pois, no limite, para eles vale mais o ditado: “de Deus não se zomba”.

Talvez seja este um dos principais motivos pelos quais dificilmente ocorrerá de um cultuante reformado, durante a liturgia, apresentar "má" nifestações emocionais e corporais de natureza extática. Ademais, não se pode esquecer das palavras normatizadoras do apóstolo Paulo, escritor neotestamentário muito caro aos reformados:

29 OTTO, 2007, p. 47. 
"Rogo-vos pois irmãos que apresenteis o vosso corpo como sacrifício vivo, santo e agradável a Deus, que é o vosso culto racional" (Romanos 12.1), ressalte-se: culto racional, apesar do corpo!

Trata-se, portanto, não de um preconceito com as manifestações extáticas, mas de uma reação-sentimento, e "sentimento de criatura que afunda e desvanece em sua nulidade perante o que está acima de toda criatura". ${ }^{30}$ Nesse sentido, o Sagrado no culto protestante reformado inspira uma solene devoção e arrebatamento ante o Mysterium Tremendum. É a autopercepção de estar na presença do Totalmente Outro, isto é, quando "me deparo com algo 'totalmente diferente', cuja natureza e qualidade são incomensuráveis para a minha natureza pela qual estaco diante dele com pasmo estarrecido". 31 É preciso sublinhar, também, que essa autopercepção pode ser "representada pelo ato de prostrar-se, ajoelhar-se, enfim, um sentimento de profunda reverência bem como um reconhecimento da alteridade ontológica da divindade levava o homo religiosus a prostrar-se na presença do Totalmente Outro". ${ }^{32}$

Ora,

como cristãos, sem dúvida, nos deparamos inicialmente com sentimentos que de forma atenuada também conhecemos em outras áreas: sentimentos de gratidão, de confiança, de amor, de esperança, de humilde sujeição e submissão. Só que isso não esgota o momento de devoção, nem apresenta os traços muito específicos e exclusivos do "solene", que caracteriza o singular arrebatamento a ocorrer somente então. ${ }^{33}$

Há que se ressaltar que no culto protestante, além do Mysterium Tremendum, outro aspecto do numem que tem estreita relação com o acento teológico reformado da soberania de Deus é o Tremenda Majestas. Para Otto, tal aspecto aponta para uma "inacessibilidade absoluta", a qual é simbolizado em termos como poder, domínio, hegemonia e supremacia absoluta. Ora, nada mais naturalizado na teologia reformada do que a doutrina da soberania de Deus. Assim, o aspecto "majestoso" está sempre permeando o culto presbiteriano.

Mas esse aspecto majestoso tem características peculiares que o diferem, em certo sentido, do Mysterium Tremendum. Para Otto,

\footnotetext{
OTTO, 2007, p. 41.

OTTO, 2007, p. 59.

32 LOPES, Marcelo. Impressões de uma ausência: apontamentos (quase despretensiosos) acerca de um objeto de cultura material religiosa no culto cristão de matriz protestante - o caso do genuflexório. Protestantismo em Revista, São Leopoldo, v. 36, p. 138-150, jan./abr. 2015. p. 141-142. Disponível em: <http:// periodicos.est.edu.br/index.php/nepp/article/view/2392/2327>. Acesso em: 20 jun. 2015.

33 OTTO, 2007, p. 40.
} 
sombra e reflexo desse aspecto absolutamente avassalador, essa majestas é aquele "sentimento de criatura" que contrasta com o avassalador, sentido objetivamente; trata-se de uma sensação de afundar, ser anulado, ser pó, cinza, nada, e que constitui a matéria-prima numinosa para o sentimento de "humildade" religiosa. [Ademais], majestas e "ser pó e cinza" levam, por um lado, à aniquilação [annihilatio] do si-mesmo e por outro, à realidade exclusiva e total do transcendente. ${ }^{34}$

Subscrever a teoria de Otto nessa nossa análise, não significa, necessariamente, afirmar que o cultuante na liturgia reformada se anula completamente, mas que suas percepções do sagrado e suas experiências são pautadas por um acento teológico o qual já destacamos anteriormente. De outro modo, suas reações e interações com o sagrado têm um escopo específico, qual seja, de que o Soberano Deus seja, de fato, soberano no culto.

\section{Considerações finais}

A modo de conclusão, é preciso reconhecer que há muito da teoria de Rudolf Otto sobre o sagrado que não abordamos neste texto. Essa lacuna tem dois motivos principais. O primeiro deles foi nossa opção por uma chave hermenêutica que não forçasse o objeto, isto é, tomamos o lastro teológico-doutrinário reformado presbiteriano em sua ênfase cúltica e correlacionamos os aspectos do sagrado aventados por Otto que mais se aproximavam de uma interpretação verossímil do sagrado no culto reformado. O segundo motivo tem relação com a própria extensão necessariamente breve desse ensaio, pois não é possível aprofundar, com o devido aporte teórico-metodológico, dois assuntos dessa magnitude: o sagrado e o culto protestante.

A despeito disso, nosso esforço heurístico deu-se no sentido de proporcionar ao leitor uma brevíssima sinopse histórica do culto reformado no Brasil, apresentar os dois modelos de culto mais adotados pelos protestantes; além, é claro, de problematizar sumariamente, aspectos do sagrado no culto reformado, e isso de forma endógena. Portanto, não tivemos pretensão alguma de exaurir o assunto ou propor questões totalizantes ou peremptórias. Nosso fulcro foi muito mais de alçar essa temática muito cara a nosso ver, do que propor reduções monolíticas.

Por fim gostaríamos de terminar com Otto:

Mas onde quer que sopre o espírito, os termos racionais da proclamação da palavra, embora geralmente provenham da vida psíquica comum, já bastam e são vigorosos o suficiente para fazer a psique sintonizar-se imediatamente. O despertar daquilo que eles apenas esboçam acontece por si só, praticamente dispensa ajuda. Quem lê as Escrituras "no espírito", vive no numinoso, mesmo que deste não tenha conceito nem nome, mesmo

34 OTTO, 2007, p. 52. 
que seja incapaz de analisar seu próprio sentimento para nele identificar aquela trama entretecida do numinoso. 35

\section{Referências}

BASTIDE, Roger. O sagrado selvagem e outros ensaios. São Paulo: Companhia das Letras, 2006.

BÍBLIA TRADUÇÃO ECUMÊNICA. São Paulo: Loyola, 1994.

BICALHO, Maria Fernanda B. A França Antártica, o corso, a conquista e a "peçonha luterana". História, São Paulo, n. 27, v. 1, p. 29-50, 2008. Disponível em:

<http://www.scielo.br/pdf/his/v27n1/a04v27n1.pdf>. Acesso em: 25 dez. 2016.

CAMPOS, Leonildo Silveira. Pentecostalismo e Protestantismo Histórico no Brasil: um século de conflitos, assimilação e mudanças. Horizonte, Belo Horizonte, v. 9, n. 22, p. 504533, jul./set. 2011. Disponível em:

<http://periodicos.pucminas.br/index.php/horizonte/article/view/P.2175-

5841.2011v9n22p504/2909>. Acesso em: 20 maio 2015.

CHEVITARESE, André Leonardo. Cristianismos: questões e debates metodológicos. Rio de Janeiro: Klinē, 2011.

CUNHA, Gladson Pereira da. O culto presbiteriano como performance do tempo sagrado. Protestantismo em Revista, São Leopoldo, v. 31, p. 94-108, maio/ago. 2013. Disponível em: <http://periodicos.est.edu.br/index.php/nepp/article/viewFile/795/1035>. Acesso em: 25 dez. 2016.

ELIADE, Mircea. O sagrado e o Profano: a essência das religiões. São Paulo: Martins Fontes, 2008.

KNAUSS, Paulo. No rascunho do Novo Mundo: os espaços e os personagens da França Antártica. História, São Paulo, n. 27, v. 1, p. 143-153, 2008. Disponível em:

<http://www.scielo.br/pdf/his/v27n1/a09v27n1.pdf>. Acesso em: 25 dez. 2016. Grifo nosso.

LOPES, Marcelo. Impressões de uma ausência: apontamentos (quase despretensiosos) acerca de um objeto de cultura material religiosa no culto cristão de matriz protestante - $\mathrm{o}$ caso do genuflexório. Protestantismo em Revista, São Leopoldo, v. 36, p. 138-150, jan./abr. 2015. Disponível em:

<http:// periodicos.est.edu.br/index.php/nepp/article/view/2392/2327>. Acesso em: 20 jun. 2015.

MARIZ, Vasco; PROVENÇAL, Lucien. Villegagnon e a França Antártica: uma reavaliação. Rio de Janeiro: BibliEx/Nova Fronteira, 2001.

35 OTTO, 2007, p. 101. 
MATOS, Alderi Souza de. A França Antártica e a Confissão de Fé da Guanabara. CPAJ. Disponível em: <http:/ /www.mackenzie.br/6996.98.html>. Acesso em: 25 dez. 2016.

MENDONÇA, Antonio Gouvêa. A crise do culto protestante no Brasil. Estudos de Religião, São Bernardo do Campo: UMESP, ano 1, n. 2, p. 31-60, out. 1985.

MENDONÇA, Antonio Gouvêa. O celeste porvir: a inserção do protestantismo no Brasil. São Paulo: ASTE/Pendão Real; São Bernardo do Campo: IMS, 1995.

OTTO, Rudolf. O Sagrado: aspectos irracionais na noção do divino e sua relação com o racional. São Leopoldo: Sinodal/EST; Petrópolis: Vozes, 2007.

REILY, Duncan Alexander. O culto no Protestantismo Puritano-Pietista. Estudos de Religião, São Bernardo do Campo, ano 1, n. 2, p. 89-102, out. 1985.

VELASQUES FILHO, Prócoro. O culto protestante: características, ênfases e teologia. Estudos de Religião, São Bernardo do Campo, ano 1, n. 2, p. 61-85, out. 1985. 